\title{
Teaching Recorder: Creating Excitement in the Instrumental Music Classes
}

\author{
Alan Caldas Simões* \\ School of Music, Federal University of Rio de Janeiro, Rio de Janeiro, Brazil \\ *Corresponding author: alanmp@yahoo.com.br
}

Received August 25, 2014; Revised September 01, 2014; Accepted September 16, 2014

\begin{abstract}
In this paper we describe strategies for teaching recorder in elementary school. We seek to answer the following question: How to develop teaching strategies that allow students to make music since the first lesson in a pleasant, and appropriate to their musical environment, age and technical level? Traditional musical education focuses on the teaching of instrumental technique and musical notation. These approaches may inhibit or discourage beginner's music students. Furthermore, in many cases, the repertoire chosen by the teacher does not take into account the student's everyday lives. Thus we developed a recorder method for beginners based on the principles of learning folk musicians, seeking technical and theoretical work in context and meaningful to the student. This method was applied during the year 2013-2014 in four classes of elementary school in Brazil. In our article, we describe the process of creating songs for beginners and the results of its application in the classroom. We present the scores for these songs and analyze their implications for teaching and learning music. The results indicate that: (a) the style, arrangement and technical level of execution of songs worked on in the classroom can be determinant stimulus for beginner students continue with their musical studies; (b) approaches that value the music active listening allow the student to develop increased autonomy in the classroom; and (c) an exciting musical practice should take into account age, musical knowledge and student's reality.
\end{abstract}

Keywords: teaching recorder, meaningful learning, repertoire, new approaches to teaching music, music in elementary school

Cite This Article: Alan Caldas Simões, "Teaching Recorder: Creating Excitement in the Instrumental Music Classes.” American Journal of Educational Research, vol. 2, no. 9 (2014): 828-831. doi: 10.12691/education-2-919.

\section{Introduction}

\subsection{The Field of Instrumental Music Education}

The field of instrumental music education has a tradition of teaching practices that are based on the master-disciple relationship, where the teacher is an example to be followed faithfully by the student. Thus are stimulated practices like repetition, memorization and maintenance a classical and romantic repertoire, emphasizing on music reading notation.

These approaches may inhibit or discourage beginner's music students. The teaching repertoire chosen by the teacher, sometimes, does not take into account the student's everyday lives. These students seek to make music as soon as possible without the need for lengthy theoretical explanations about the nature of music and how to play an instrument. However, there are several ways to develop a work of instrumental and vocal music education that allows the student an education committed to the nature of artistic and musical language $[1,2,3]$.

We can illustrate this reality through projects or groups of collective teaching of musical instruments. By using a methodology which attempts to integrate inherent aspects of music education and to promote a process of social transformation of its participants, the instruction may develops a critical sense and awareness of the role of art in life and in society as a whole [4,5].

We understand that the ultimate goal of music lessons in school is making music as soon as possible, or in other words, put the student in contact with the musical instrument with the purpose of musical realization (performance) and promote a process of active experience with the musical language. When the students learn the basic fingerings of the instrument and the first notes, they are ready to play, even though using simplified arrangements [6].

\subsection{The Recorder in the Classroom}

Commonly, when we think of music learning, comes to our mind the possibility of learning to play a musical instrument or singing. Within the school environment this idea is no different, even though we know that there are several approaches in music education where performance is not the main focus of the musical learning process [7].

Each student to initiate his musical studies, whether or not in specific schools, has within it a particular motivation that influenced him or her to start and continue their musical studies. Perhaps the main one is learning to 
play the songs that suit you, in other words, songs that are part of their life history and cultural context. In this sense, the selection of repertoire to be used in the classroom becomes essential to begin a process of meaningful music education. As regards of music education for children, especially in elementary school, these individual motivations are accompanied by a natural impatience of the student who seeks 'make music' as soon as possible, without the need for lengthy theoretical expositions and play a familiar repertoire, often played on radio, television and internet.

In our practice as teachers of music found several obstacles to overcome within the school environment to teach recorder. First, often the recorder is seen suspiciously by the student, because its timbre and physical appearance do not exert the same fascination about it that other musical instruments as: acoustic guitar, electric guitar, electric bass, drums and saxophone, etc. We also point out that the recorder has a relatively small extent compared to other instruments. So the teacher often must work in middle regions of the recorder, making whenever possible adjustments in the songs to be worked on the classroom, for better adaptation to the technical level of the student.

The main challenges of teaching recorder in Brazilian elementary schools include: (a) diversity of musical abilities end stimulus to learn music in the classroom; (b) arrange in a same space different instruments like percussion, recorder, acoustic guitar and keyboard, etc.; (c) selection of repertoire appropriate age and technical level of the students; (d) lack of pedagogical knowledge from the teacher; (e) overcome the legacy of 'traditional pedagogy' music teaching; (f) sometimes the student does not practice at home and his only contact with the instrument is the day of class; (g) pressure from school to follow a school calendar of presentations (quick formation of students); and (h) think of the musical quality of students' work without giving priority to music notation and instrumental technique.

\section{Purpose of the study}

In this article, we seek to answer the following question: How to develop teaching strategies that allow students to make music since the first lesson in a pleasant, and appropriate to their musical environment, age and technical level?

In order to answer our research question, we developed a recorder method for students beginners (about 6-10 years old), based on the principles of how popular musicians learn music, seeking technical and theoretical work in context and meaningful to the student. This method was applied during the year 2013-2014 in four classes of elementary school in Brazil.

\section{Materials and Methods}

To create this method we have adopted the following principles: (1) the instrumental practice should be performed before reading music; (2) it is necessary that the student play since the first day of class using the basic principles learned in each lesson; (3) for each new note or technique learned there will be a song to be worked; (4) the practice of the repertoire in the classroom becomes a collective study of the teacher with students. Now the technique is not studied in an isolated way, but in musical context, always held on the rhythmic-harmonic accompaniment styles using as basic musical patterns derived from pop music; (5) songs created must be learned by ear.

\section{Results and Discussion}

The following section we present part of the songs contained in our method as well as a brief analysis on the same. The playbacks of the songs were presented here can be checked through the link: https://www.youtube.com/watch?v=3tZru3y9HbE\&featur $\mathrm{e}=$ youtu.be.

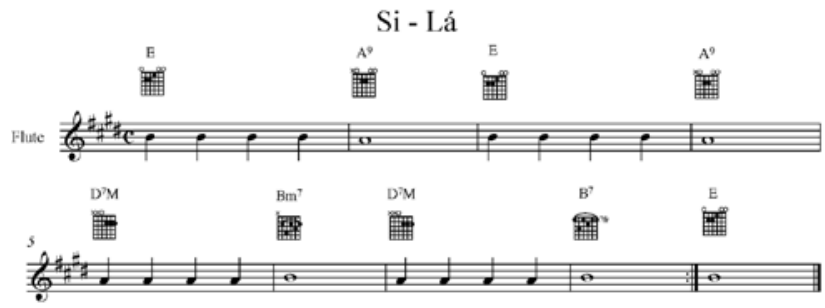

Figure 1. Composition $n^{\circ} 1$

The song "Si-Lá" (Figure 1) uses only two notes, B and A. The first phrase of the melody is ascending and the second phrase is descending. Usually the notes B and A are the first two notes to be learned on the recorder. In this song we created an intentional repetition of rhythm and notes. The student will just have to hold the index finger and thumb on the first top hole and bottom hole of the recorder. Therefore be used only the index finger, which will be raised to execution of note $B$ and lowered for execution of note A.

This music can be used with children starting from 6 years of age. In our practice we obtained satisfactory results in terms of execution and the sonority on the recorder. The use of harmonic accompaniment during the execution of the song proved to be essential to integrate the student into a collective musical practice in the classroom and improve their tuning.

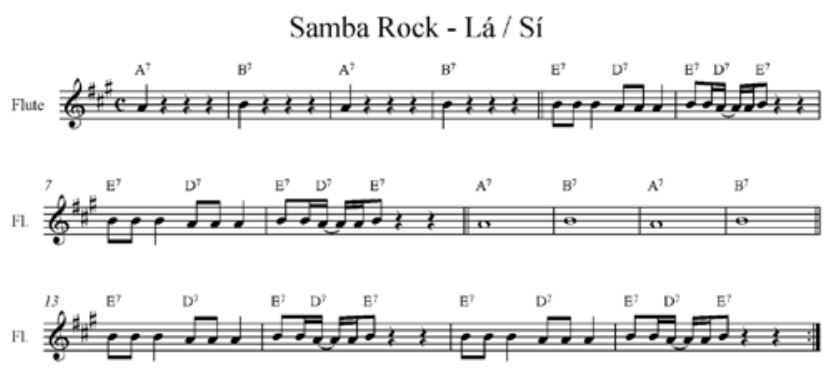

Figure 2. Composition $n^{\circ} 2$

In the song "Samba Rock Lá / Sí" (Figure 2) we use the same notes of the song "Sí-Lá". However, we emphasize the syncopated rhythm. The melody has notes that are attacked together with harmony, facilitating the conduction of the song, even in moments of silence (pauses). The use of samba rock style on the guitar contextualizes the melody and to becomes a stimulating element for the student. We note that the style of rhythmic accompaniment is essential to stimulate the student to 
learn a new song and consider their performance as a fun activity in the classroom.

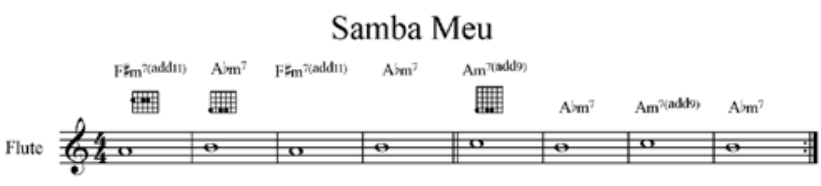

Figure 3. Composition $n^{\circ} 3$

The song "Samba Meu" (Figure3) introduces the student to the style of bossa nova. Thus, we have a simple melody sustained by dissonant chords in syncopated rhythm. There again we work with the notes B and A. Now, instead of just lowering and raising the middle finger, the student must switch the index and middle fingers, producing the note $\mathrm{C}$ and $\mathrm{B}$. This exercise will allow students gain agility and precision in the execution of recorder.
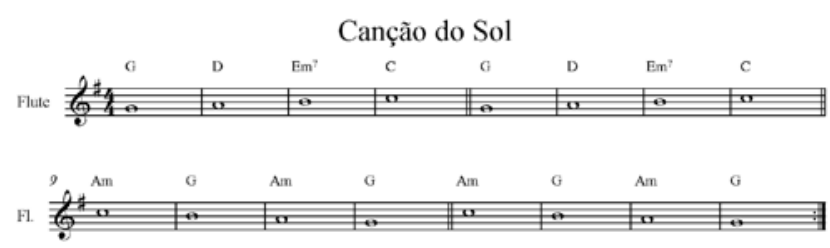

Figure 4. Composition $n^{\circ} 4$

In the song "Canção do Sol" (Figure 4) was worked the first four notes of the $G$ major scale in ascending and descending order. This music can be performed with different gaits and variations of harmonic accompaniment. Thus, we can start using the pop music style and in the second repetition change the style to reggae or rock music, and so on. Consequently, the student will exercise the scales in a contextualized way, without bothering with the rehearsal exercise, because each repetition will have the impression of performing a new song.

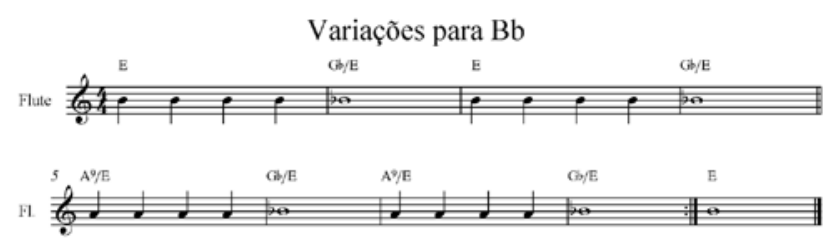

Figure 5. Composition $n^{\circ} 5$

In the song "Variações para Bb" (Figure 5) we started the student in different harmonic sonority and work for the transition from $\mathrm{B}$ to $\mathrm{Bb}$ notes, using as the basic framework the song "Sí-Lá". We know that this passage is not common for beginners, but noted that the $\mathrm{Bb}$ position facilitates learning of the note $\mathrm{F}$ (in Germanic recorder) because we add only the middle finger in the hole two (Bb to F).

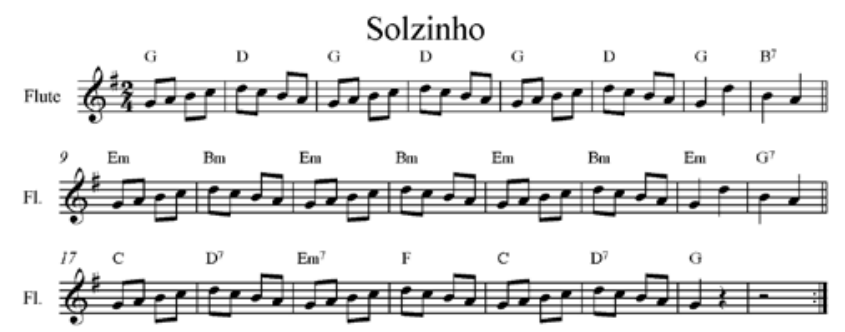

Figure 6. Composition $n^{\circ} 6$
The song "Solzinho" (Figure 6) is a continuation of the technical elements learned in the song "Canção do Sol". When executing the $\mathrm{G}$ pentacorde in ascending and descending order, the student exercise the agility and precision in the first three positions of the recorder. The harmonic changes promote movement in the melody, indicating harmonic modulations for different areas, although the melody remains using the same notes.

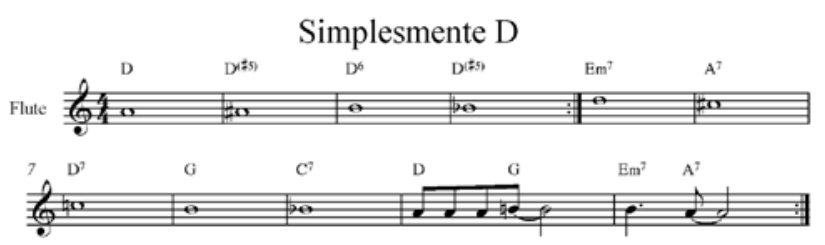

Figure 7. Composition $n^{\circ} 7$

In the song "Simplesmente D" (Figure 7) was worked the ascending chromatic passage from $\mathrm{A}$ to $\mathrm{Bb}$ and descending chromatic passage from $\mathrm{Bb}$ to $\mathrm{D}$. The harmonic accompaniment is permeated by dominant chords that facilitate chromatic transitions. We believe that the acquisition chromatic vocabulary allows a gradual introduction of the student to execution of new tones. These chromatic passages use the note $C$ sharp, which has a similar position to note A, simply by removing the thumb from the bottom hole of the recorder.

\section{Conclusions}

Teaching any musical instrument is always a challenge and invites the teacher to constantly revise their pedagogical practices. Our method is one of the many possibilities we have to teach recorder in elementary school. We seek not format a rigid method of teaching, but only highlight some pedagogical and musical principles that can make the process of teaching stimulating and meaningful for the student.

In our practice we have observed that one of the musical elements that promote more excitement in the classroom is songs with danceable rhythms and harmonic patterns familiar to students. We defend the following thesis: we should start teaching a musical instrument not for familiar melodies, but for familiar harmonies and rhythms. This principle is able to create a meaningful musical environment in the classroom.

Of course I do not deny the importance of popular culture in society, but it seems to me, that working with pop songs is able to mobilize the student from elementary school in a more natural and efficient way. Always remember that we are talking about the beginner's music students. Why not work since the first music lessons using: reggae music, funk, rock, bossa nova, samba, country music, soul, dance, blues, folk, pop music? What holds us back?

Many music teachers do this. This is not news to anyone, but we need to create theoretical foundations that allow us to investigate this phenomenon more closely, aiming to expand the quality of instrumental music education in regular schools. I know that I must still investigate this issue more closely, but my feeling as a music teacher, tells me that we should reverse what we normally do in teaching musical instruments. 
After the application of our method, we conclude that: (a) the style, arrangement and technical level of execution of songs worked on in the classroom can be determinant stimulus for beginner students continue with their musical studies; (b) approaches that value the music active listening allow the student to develop increased autonomy in the classroom; and (c) an exciting musical practice should take into account age, musical knowledge and student's reality.

Therefore we believe that it is possible musical practice that exercises gradually instrumental technique without the rigor of traditional musical education. Finally we hope that our article and ideas can inspire other music teachers to develop in their students the joy and the pleasure of making music in school. Independently of the method or repertoire chosen to work in the classroom I think that experience of teaching music in the elementary school should expand qualitatively and quantitatively the musical universe of the student, making the classroom and music classes an enjoyable and exciting time for everyone.

\section{References}

[1] Cruvinel, F. M, Educação Musical e Transformação social: Uma experiência com ensino coletivo de cordas, Instituto CentroBrasileiro de Cultura, Goiânia, 2005.

[2] Paz, E. A, Pedagogia Musical Brasileira no Século XX, MusiMed, Brasília, 2013.

[3] Sindberg, L. K, Just good teaching: comprehensive musicianship through performance (CMP) in theory and practice, Rowman \& Littlefield Education, Lanham, Md., 2012.

[4] Almeida, J. C, "O ensino coletivo de instrumentos musicais: Aspectos históricos, políticos, didáticos, econômicos e socioculturais. Um relato," in Proceedings of the I Encontro Nacional de Ensino Coletivo de Instrumento Musical, UFG, 1-10, 2004.

[5] Álvares, S. A, "Incorporating traditional Choro music experiences into Brazilian university music curricula through class instruction using comprehensive musicianship concepts," in Proceedings of the 30th ISME World Conference on Music Education, ISME, 120-125, 2012.

[6] Tourinho, A. C. G. S, "Ensino Coletivo de Instrumentos Musicais: crenças, mitos, princípios e um pouco de história," in Proceedings of the 16th Encontro Nacional da ABEM, ABEM, 50-60, 2007.

[7] Ilari, T. M. B, Pedagogias em Educação Musica, Inter Saberes, Curitiba, 2012. 